\title{
Węgierska parodia filmowa. Skutki uboczne parodii filmowych z czasów Kádára
}

Węgrzy - naród europejski, posługujący się szczególnym językiem z ugrofińskiej grupy językowej (dla nie-Węgrów całkowicie niezrozumiałym i mało kto jest w stanie nauczyć się go w wieku dorosłym...), osamotnieni w Europie Środkowej w morzu słowiańsko-germańskim, ze szczególną skłonnością do smutku (prawdopodobnie z powodu pewnych tragicznych wydarzeń w ich nowszej historii), od dawna zajmując najwyższe szczeble w statystyce samobójstw - mają godne podziwu poczucie humoru. W kulturze i sztuce nowoczesnej specyficzne wyczucie wobec dowcipu przejawia się często i w różnorakich postaciach, przy czym niepowtarzalną rolę odgrywa także wyrafinowana imitacja innych dzieł, gatunków, stylów czy wyrażanie cech i właściwości ludzkich - czyli parodia.

Parodia zadomowiła się w nowoczesnej kulturze węgierskiej, znalazła swój wyraz w różnych formach, objawia się w rozmaitych kontekstach za pośrednictwem różnych gatunków i stylów, najczęściej dochodzi do głosu przede wszystkim na scenach kabaretowych, w skeczach radiowych i telewizyjnych, ale i w utworach muzycznych i w literaturze. Za klasyczny przejaw mistrzostwa parodii narodowej uchodzi tekst Frigyesa Karinthy’ego Tak oto piszecie (Így írtok ti), będący zbiorem imitacji literackich stylów największych węgierskich pisarzy (poetów, prozaików), który po raz pierwszy został wydany w formie książkowej w roku 1912 i do dziś jest na Węgrzech nadzwyczaj popularny.

O uprzywilejowanym statusie parodii w tej kulturze świadczy na przykład i to, że kiedy na ekranach telewizji państwowej na początku lat 6o. wystartował konkurs młodych talentów „Co kto wie?” (Ki mit tud? - poprzednik współczesnych megashows typu „Idol”), obok „poważnych” kategorii, jak recytacja poezji i prezentacja prozy czy interpretacja pieśni ludowej i tańca, równoprawną dyscypliną konkursową była parodia - jako samodzielna, odrębna kategoria. Na zasadach parodii opierały się występy jednego z najpopularniejszych humorystów późniejszej doby kádárowskiej i lat po przewrocie demokratycznym (lata 70.-90.) Gézy Hofi, którego scenki telewizyjne i monologi uchodzą do dziś za osiągnięcie w kulturze popularnej, któremu nie można dorównać, a przy tym stanowią wyjątkowy twórczy wkład w dziedzinie narodowej autorefleksji.

Gdybyśmy jednak chcieli znaleźć znaczące ślady obecności parodii w kinematografii węgierskiej, napotkamy trudności. W produkcji filmowej od czasów powojennych aż po współczesność trafimy na wiele 
zabawnych, pełnych dowcipu filmów obejmujących różne postacie komedii, satyrę, fraszkę lub burleskę, ale rasowych parodii jakoś brak. Dlaczego? Przyjrzyjmy się pewnym konkretnym przykładom, a ich analiza krytyczna może przyniesie wyjaśnienie tego problemu.

Węgierski James Bond?
Kiedy w roku 1969 na ekrany kin weszła pierwsza i jedyna parodia filmu z Bondem, wspaniały barwny, szerokoekranowy film Lew pręży się do skoku (Az Oroszlán ugrani készül) w reżyserii György’a Révésza, w kinach na Zachodzie wyświetlano już piątego Bonda (You Only Live Twice, Żyje się tylko dwa razy, ostatni z pięciu filmów z Seanem Connerym w roli agenta 007). Film staje się kultowy, gdy doczeka się swej parodii. „Bondy”, które obeszły już po całym świecie, parafrazowano już wielokrotnie - co prawda z różnym skutkiem[1].

Ale dlaczego parodię Bonda nakręcają pod koniec lat 6o. w socjalistycznych Węgrzech, kiedy tam do tej pory nie wyświetlono jeszcze żadnego filmu z Bondem? Fenomen superszpiega brytyjskich tajnych służb, walczącego przeważnie z przeciwnikami z drugiej strony żelaznej kurtyny (często są to agenci KGB), praktycznie nie był znany. Choć od połowy lat 6o. można już mówić o pewnej liberalizacji stosunków społeczno-politycznych w kádárowskich Węgrzech, a kultura otwierała się na wpływy zachodnie, powieści Fleminga nie wydawano ze zrozumiałych powodów ideologicznych, a filmowych „Bondów” nie wprowadzano do kin aż do lat 8o. Skąd więc ta parodia?

Przyjrzyjmy się najpierw samej treści opowieści zawartej w filmie Lew pręży się do skoku. Jest prosta, może nawet nieco prymitywna. Dr Otto Klauberg, były lekarz nazistowski, po latach wychodzi z więzienia. Stylizuje się na ofiarę okoliczności, bo w czasie wojny poświęcał się wszak wyłącznie nauce, badaniom medycznym - produktem badań była również bardzo niebezpieczna szczepionka ze śmiercionośną bakterią. Człowiek, w którego rękach po latach znajdą się fiolki z bakteriami, będzie miał nieograniczoną władzę nad ludzkością. Podejrzane szczepionki lekarz przechowuje w nieznanym miejscu. Chcą je również wykorzystać byli kompani Klauberga. Na szczęście w samą porę i we właściwym miejscu pojawi się węgierski superagent Menő Fej (Mądra głowa), w którego rolę wcielił się dwudziestosiedmioletni popularny aktor István Bujtor. Sympatyczny agent jest dobrze przygotowany, aby uratować świat, przy czym udaje się mu jeszcze uwikłać we flirt $\mathrm{z}$ atrakcyjną córką Klauberga - Ewą (Ilona Medveczky).

Jeśli chodzi o historię, to właściwie wszystko - film wypełniają mniej lub bardziej udane sceny akcji: pościgi samochodów, strzelaniny, kilka pojedynków głównych postaci filmu (przy tym parę ciosów nie
[1] Na przykład za niezbyt udaną parodię uważa się powszechnie Cassino Royale z roku 1967, z Davidem Nivenem, Peterem Sellersem i Woodym Allenem w rolach głównych. Ale żarty filmowe na rachunek superagenta tajnych służb zrealizowali z mniejszym lub większym sukcesem także inni twórcy: Jean Paul
Belmondo (Człowiek z Acapulco, 1973), Pierre Richard (Tajemniczy blondyn w czarnym bucie, 1972), Leslie Nielsen (Agent WC 40, 1996), Mike Myers (Austin Powers, 1997) czy Rowan Atkinson (Johny English, 2003) i wielu innych. 
tylko rozda, ale także odbierze - w roli jednego z gangsterów - autentyczny węgierski mistrz olimpijski w wadze lekkiej László Papp). Istotną rolę odgrywa również atrakcyjna sceneria, film był kręcony w kilku miejscach ówczesnej Jugosławii, przede wszystkim w chorwackim Dubrowniku oraz w bośniackim Mostarze. Nie brakuje również „bondowskich" usprawnień technicznych: gadająca fajka lub ultradźwiękowe urządzenie, którym można unieszkodliwić rozmówców na drugim końcu przewodu telefonicznego...

Przyjrzyjmy się w końcu problemowi, jaki jest sens węgierskiej parodii, której przedmiotem jest nieznany fenomen kulturowy. Fakt, że w krajach obozu socjalistycznego nie wydawano przygód agenta $007 \mathrm{w}$ formie książkowej, a w kinach ich nie wyświetlano, nie znaczy jeszcze, że sam bohater nie był znany. Chociaż w latach 6o. i na początku 70. nie mamy jeszcze do czynienia $\mathrm{z}$ alternatywną dystrybucją filmów na kasetach VHS, to jednak atrakcyjność kultu Bonda przesączała się przez żelazną kurtynę. Pomimo oficjalnej niechęci wobec tego motywu fala popkultury wywarła wrażenie także na Wschodzie, a o fenomenie Bonda przynajmniej wspominały popularne magazyny (zwłaszcza filmowe). Wyobrażenia na temat bohatera i jego filmowego świata uzupełniały fotografie prasowe itp. Cóż, i tak zjawisko Bonda w granicach możliwości - zainteresowało i zachwyciło masy konsumentów ze Wschodu. Fascynacja tego typu mogła być ostatecznie jedną z przyczyn, które wpłynęły na nakręcenie węgierskiej parodii Bonda Lew pręży się do skoku.

O prawdopodobieństwie tej hipotezy świadczą wreszcie przykłady współczesnych filmów z innych kinematografii socjalistycznych. Wymowne są w tym względzie z pewnością niektóre czechosłowackie tytuły: komedia Lemoniadowy Joe z roku 1964, która przyniosła parodystyczną interpretację amerykańskich westernów, opierała się raczej na pamięci o międzywojennych przedstawieniach filmowych (westerny na ekrany kin czechosłowackich wracają w ciągu lat 6o.), podobnie film Kto chce zabić Jessie? (1966), parodiujący świat komiksów, odwoływał się w tym czasie do wyobrażeń o tym gatunku, ponieważ poza nielicznymi wyjątkami komiksów niemal nie wydawano. Koniec agenta $W_{4} \mathrm{C} z a$ przyczyna psa pana Foustky z roku 1967 musiał całkowicie odwołać się do wyobraźni widzów na temat szpiegostwa w typie „Bonda”, ponieważ w socjalistycznej Czechosłowacji nie pokazywano filmów z agentem oo7.

Bohater o nadprzyrodzonych zdolnościach po prostu inspiruje twórców ze Wschodu, a także pozwala zakładać, że przyciągnie masowego odbiorcę. Ta nadzieja się spełni. Jednym z „bezpiecznych” sposobów, jak w warunkach socjalistycznej kinematografii zagrać z superbohaterem - jak również nacieszyć się wspaniałym światem zdecydowanych postaw i twardych pięści, szybkich samochodów i pięknych kobiet, w którym to świecie dobro zawsze wygra ze złem - było nakręcenie parodii o tym wszystkim. „Bond” na Zachodzie i jego socjalistyczna parodia w dużej mierze odpowiadają na podobne oczekiwania widzów, te same potrzeby iluzji, przy czym parodia ma i tę wielką zaletę, że jest 
znacznie tańsza - na przykład dlatego że jej triki nie zawsze muszą być doskonałe, wystarczy, jeśli są śmieszne. W każdym razie w socjalistycznych parodiach zachodnich wzorców kulturowych mieszała się najczęściej stonowana drwina oraz ironia z dość dużym (czasem nawet trudnym do ukrycia) podziwem dla parodiowanego fenomenu.

Prawdą jest, że ówczesna fascynacja konkretnym kultem nie wystarczyłaby, aby nakręcać parodie w socjalistycznych studiach filmowych. Nadal byłoby to za mało. Należało jakoś uspokoić cenzurę chociaż liberalizacja życia już ją nieco osłabiła, była wciąż czujna. I tak elementem socjalistycznych parodii filmowych stawał się za każdym razem przynajmniej zaznaczony „właściwy” klasowy punkt widzenia lub przynajmniej pożądane wartości. W filmie Lew pręży się do skoku jest to relatywnie nienachalnie, ale równocześnie jednoznacznie wyrażone: „nasz” agent walczy z przedstawicielami złego, zachodniego świata, który jest powiązany z mroczną nazistowską przeszłością.

Pomimo wątłej fabuły i wielu innych niedostatków po wprowadzeniu go na ekrany film odniósł znaczny sukces. Dziś trudno byłoby szczegółowo przeanalizować, jak wielki udział w tym sukcesie miały poszczególne elementy dzieła (sceny akcji, nowoczesne, zaawansowane rozwiązania techniczne i filmowe triki czy popularność poszczególnych bohaterów etc.), a co jest zasługą siły przyciągania fenomenu „Bonda” jako takiego. Kiedy film po niemal czterech dekadach w roku 2008 pojawił się na DVD, okazało się to wszystko nieaktualne, magia prysła. Technika i triki są ewidentnie przestarzałe, kult gdzieś wyparował...

Kojak w Budapeszcie

U progu lat 8o. zawitał do Budapesztu inspektor Theo Kojak. Ściśle mówiąc, w roku 1980 na ekran weszła węgierska parodia Kojak w Budapeszcie (Kojak Budapesten, reż. Sándor Szalkai), inspirowana postacią głównego bohatera amerykańskiego serialu telewizyjnego Kojak, który stacja CBS emitowała w pięciu seriach (ponad 120 odcinków) w latach 1973-1978. Lata 70. i 8o. należały w węgierskiej telewizji do zachodnich seriali kryminalnych, takich jak Colombo, Derrick i Kojak, które miały nadzwyczajne powodzenie wśród publiczności.

U źródeł węgierskiej parodii policjanta z Manhattanu leżała raczej jeszcze raz miłość i podziw dla samego fenomenu - policjanta z lizakiem i szczególnego świata, który otaczał go w każdym epizodzie niż jakaś spójna, precyzyjna i bezpośrednia drwina z natury i konwencji gatunkowych oraz klisz filmów detektywistycznych. Dowodem na to jest w końcu fakt, że pierwotnym zamiarem węgierskich filmowców było pozyskanie do nakręcenia budapesztańskich przygód inspektora Kojaka samego amerykańskiego odtwórcy tej roli - aktora z greckimi korzeniami Telly Savalasa. Twórcy przedstawili taką ofertę w trakcie telefonicznych rokowań z gwiazdą telewizyjną[2]. Wypełniony kalendarz

[2] Tak we wspomnieniach Gwiazda światowej sławy zażądała horrendalnej gaży za swą rolę w filmie „Kojak w Budapeszcie” (Horrorisztikus gázsit kért a világsztár a budapesti szerepért. Kojak Budapesten), zamieszczonych na portalu 168, pisze László Bokor; zob. <http://www.168ora.hu/itthon/kojak-telly-savalas-film-nemeskurty-inke-laszlo-dozsa-laszlo-krimi-65485.html> [dostęp: 6 października 2013]. 
Savalasa, a zwłaszcza jego roszczenia w kwestii honorarium, stały się powodem, dla którego pierwotny projekt kryminału ostatecznie okazał się parodią serii, na domiar - ze znaczącymi „skutkami ubocznymi“. Co się właściwie stało?

Przede wszystkim w rolę nowojorskiego detektywa, który w stolicy Węgier odwiedza międzynarodowy kongres autorów kryminałów, wcielił się aktor László Inke, który użyczył swego głosu głównemu bohaterowi w dubbingu serialu Kojak w telewizji węgierskiej. Kojak w interpretacji Inkego przemawiał głosem, z którym widzowie węgierscy już go sobie identyfikowali. Szczególna stylistyka wypowiedzi, niektóre $\mathrm{z}$ typowych zwrotów i bon moty w trakcie przetwarzania tematu przeniesione zostały w kontekst parodii. Utożsamieniu aktora z postacią Kojaka pomogła również podobna fizyczna dyspozycja (w obu przypadkach słuszna postawa), a także porównywalna fizjonomia (osiągnięcie idealnej łysiny kojakowskej nie wymagało specjalnych zabiegów...). Wykorzystanie tych samych elementów kostiumu (charakterystyczny kapelusz, doskonale dopasowany garnitur z nieodłączną kamizelką) czy użycie rekwizytów (okulary, kulisty lizak na patyku) jest w dopracowaniu iluzji dość oczywiste.

Czego doświadczy Kojak podczas swego pobytu w Budapeszcie? Nie będzie tych przeżyć mało. Przede wszystkim ujawnia swoje węgierskie pochodzenie (a więc nie greckie), dowiadujemy się, że przed laty służył w policji węgierskiej jeszcze pod prawdziwie węgierskim nazwiskiem Kócsak. Odwiedzi swego dawnego szefa, dziś naczelnika dystryktu policji budapesztańskiej, z którym niegdyś sprawował kontrolę nad placem Rakoczego (znanym z wysokiego odsetka prostytutek). Poza tym w ciągu całego filmu na życie Kócsaka-Kojaka desperacko i oczywiście bezskutecznie nastaje para zbirów, pracujących dla włosko-nowojorskiej mafii. Najważniejszy jest jednak trzeci, główny motyw. Sławny policjant, w ramach wielkodusznie zaproponowanej pomocy węgierskim kolegom, podejmie się dochodzenia w sprawie - na pierwszy rzut oka - tajemniczego zamordowania profesora geologii Lacziny. Ciało profesora, który zajmował się badaniem złóż ropy naftowej, znaleziono w jego budapesztańskim mieszkaniu. Wraz z rozpoczęciem dochodzenia parodia gatunku mimowolnie przekształca się w coś zupełnie innego, na powierzchnię wychodzą wspomniane wyżej „skutki uboczne".

Rzecz w tym, że Kojak ze swym amerykańskim doświadczeniem podchodzi do specyficznych węgierskich realiów całkiem bezstronnie i trzeba rzec - naiwnie. Tutejsza rzeczywistość jest w pojęciu filmowców bezsensowna aż do absurdu, czasem nieludzka, wręcz okrutna czy po prostu głupia. Większości perypetii, absurdalnych codziennych zmartwień i trosk, na które stale narażeni są mieszkańcy stolicy, a które ściśle wiążą się ze śmiercią profesora, zaskoczony Kojak nie jest w stanie zrozumieć i zinterpretuje je zupełnie inaczej niż nie tylko jego węgierscy koledzy policjanci, ale bez wątpienia i publiczność filmu. Właśnie to jest źródłem komizmu całej historii. 
Kojak skonstatuje na przykład w trakcie dochodzenia (i nie może tego pojąć), że w drugiej połowie miesiąca taksówki w Budapeszcie nie zatrzymują się na żądanie klientów, ponieważ w ciągu pierwszych dwóch tygodni wykonały już plan. Z wielkim zaskoczeniem bohater przyjmie wiadomość, że dyrektor przedsiębiorstwa państwowego (tak jak i jego zięć) otrzymuje zbyt wielką pensję na to, by mu wnuka przyjęto do przedszkola, a zbyt małą, by zatrudnić opiekunkę, więc w godzinach pracy osobiście doucza go w swym dyrektorskim gabinecie. Poza tym w domu, w którym mieszka Laczina, nie działa winda, akurat jest awaria wodociągu, ściany trzęsą się z powodu błędnie zaplanowanych prac ziemnych. Na domiar wszystkiego, kiedy podmokły kable, podczas telefonowania pod dowolny numer centrala każdego bez wyjątku przełącza na numer, pod którym automat opowiada bajkę O królewnie Śnieżce i siedmiu krasnoludkach... Wielość takich perypetii życiowych doprowadzi profesora do zawału - „banalnie” umrze. Naiwny Kojak podejrzewa raczej genialny spisek, doskonale funkcjonującą mafię, prawdopodobnie z centralą za granicą (wolno nam zgadywać - może w Moskwie?). Jednak naczelnik - oczywiście i widzowie - wiedzą swoje. Dla większości jest ewidentne „kto”, a właściwie „co” kryje się za „morderstwem”: rozkładający się socjalizm, wszechobecny sceptycyzm i rozczarowanie na początku lat $80 . \ldots$

Chociaż Kojak przyjeżdża do socjalistycznej metropolii z biednego skrawka południowego Manhattanu, pełnego brudu i przestępczości, to jednak elementarne rzeczy tam działają i są nazywane po imieniu: mord jest mordem, złoczyńca jest złoczyńcą, a taksówki odwożą pasażerów za wynagrodzenie w dowolne miejsce, i to przez cały miesiąc. Tamtejszy „bezlitosny” świat jest widocznie jeszcze zupełnie normalny. W odróżnieniu od niego rzeczywistość węgierska jest może bardziej bezpieczna - nie doszło wszak do morderstwa z premedytacją - tylko że wszyscy muszą żyć w świecie postawionym na głowie, w którym nic nie działa, jak powinno, i aby przetrwać, trzeba rozumieć rzeczy zupełnie inaczej niż gdzie indziej.

Wraz $\mathrm{z}$ postępem dochodzenia $\mathrm{w}$ sprawie śmierci profesora Lacziny staje się oczywiste, że w filmie Kojak w Budapeszcie z oryginalnej parodii postaci i gatunków wykluła się satyra na węgierską rzeczywistość z początku lat 8o. Wyśmiewa się i ironizuje na temat realiów życia, nie Kojaka jako postaci czy gatunku serialu telewizyjnego. Ostatecznie - czy to mało? Czy ta „zmiana zwrotnicy” jest jakimś koniunkturalnym unikiem autorów? Czy mamy do czynienia z twórczą porażką, kiedy z możliwości sparodiowania całego drzewa genealogicznego telewizyjnej popkultury film „rozpłynie się” w mniej lub bardziej zabawne porachunki z codziennością życia w socjalizmie? Nie poważę się na jednoznaczną odpowiedź. W każdym razie film został bezlitośnie potraktowany przez krytykę za powierzchowną satyrę na poziomie skeczów telewizyjnych, przy czym dane na temat kinowej widowni filmu Kojak w Budapeszcie świadczą jednocześnie o tym, że widzom „skutki uboczne” parodii jakoś nie wadziły, wręcz przeciwnie - zaak- 
ceptowali kształt końcowy[3]. Wreszcie postać Kojaka i jego historie kryminalne w zaułkach zbrodni na Manhattanie kochali i uwielbiali oglądać w telewizji, codziennie przy tym walcząc z pułapkami, jakie niosło życie codzienne.

Pozostaje jeszcze kwestia, dlaczego w kraju z bogatą i barwną kinematografią oraz subtelnym poczuciem humoru powstało przez lata tak niewiele parodii, że właściwie można je policzyć na palcach jednej ręki? Gdzie one są?

Pewną odpowiedź podsuwa nam zapewne przypadek dwóch omówionych wyżej prób parodii z historii kina węgierskiego. Ponadto dystansując się wobec konkretnych tytułów, można wysunąć hipotezę, że w najciekawszym i najbardziej płodnym okresie kina na Węgrzech (od lat 6o. do 8o.) dla kina narodowego był priorytetowy - a dzięki relatywnie liberalnemu reżimowi osiągalny - taki etos twórczy, który opierał się przede wszystkim na potrzebie uporania się z palącymi kwestiami i faktami, które są dla Węgrów trudne - zarówno obecnymi, jak i historycznymi. W kontekście tych ambicji adekwatne wydają się gatunki i formy takie, jak dramat współczesny czy historyczny, komedia, satyra czy w końcu musical, a parodia jawi się jako najmniej właściwa. Wystarczająco wiele miejsca pozostawiły w tym czasie parodii inne formy i media: kabaret, radio i telewizja.

Nie jest jednak tak, by parodii zupełnie nie było w nowszym kinie węgierskim, w pojedynczych reprezentacjach pojawia się ona stale. Nową szansę aplikowania cech parodii przyniósł w ciągu lat 90. nurt postmodernizmu. Warto wspomnieć choćby nowszą twórczość Miklósa Jancsó, który pod koniec tamtej dekady - w ramach radykalnej zmiany swej dotychczasowej poetyki - w arsenale przyjętych środków farsy, burleski, komedii absurdu i innych umieścił również elementy parodii. Jest ich wiele w epizodach pary grabarzy Kapy i Pepo, trudnych do przeoczenia bohaterów, którzy występują w całej serii nowszych filmów reżysera: Nekem lámpást adott kezembe az Úr Pesten (1998), Anyád! A szúnyogok (2000), Utolsó vacsora az Arabs Szürkénél (2001), Kelj fel, komám, ne aludjál (2002), A Mohácsi vész (2004), Ede megevé ebédem (2006), wreszcie w filmie z Danielem Olbrychskim Szlag trafit sprawiedliwość (Oda az igazság, 2010).

Miklós Jancsó, który ostatni film nakręcił u progu dziewięćdziesiątki, nie jest oczywiście jedynym filmowym „parodystą” węgierskim. Możliwości gatunku rozumieją dobrze o wiele młodsi twórcy. Warto wspomnieć filmowy debiut Attili Gigora Oficer śledczy (Nyomozó, 2008), będący wyjątkowym tyglem gatunków filmowych, którego jednym ze składników jest wyrafinowane, parodystyczne podejście do konwencji kryminału i filmu noir.

[3] W roku premiery film był najczęściej oglądanym filmem węgierskim. Spośród 45 monitorowanych filmów wyprodukowanych w latach 1979-1980 Kojak $w$ Budapeszcie zajmuje w rankingu pierwsze miejsce:
Gdzie są węgierskie parodie? do listopada 1980 roku obejrzało go 652357 widzów. Dane z artykułu: J. Veress, Mi a siker, mi a bukás? [Co to jest sukces, co to jest fiasko?], „Filmvilág” 1981, nr 1, s. 7 . 
Wreszcie możemy wspomnieć najnowszy film Béli Paczolay Poszukiwacze przygód (Kalandorok, 20o8), który właściwie rozumiał (a krytyka to odpowiednio doceniła), że nakręcenie w warunkach węgierskich „prawdziwego” filmu drogi nie może się dobrze skończyć. Dlatego w historii trzech generacji przegranych mężczyzn z jednej rodziny (dziadek, syn i wnuk), wędrujących za umykającym szczęściem życiowym między zapadłą transylwańską wioską a Budapesztem, wybrał podejście ironiczne i parodystyczne. Reżyserowi udało się wyartykułować spójne miniatury portretowe bohaterów i połączyć je z przekonującym obrazem współczesnych warunków społecznych. Całość zwieńczył parodystycznym dystansem wobec wielu standardowych praktyk i konwencji klasycznego filmu drogi, znanego z tylu „wielkich” hollywoodzkich produkcji filmowych. 